\title{
Financial Analyst Work Papers to Analysis Insurance Types Affection in Islamic Bank (Jordanian Islamic Bank Case Study)
}

\author{
Abdullah Ibrahim Nazal \\ 'Associate Professor, Department of Finance and \\ Banking, Faculty of Economics and Administrative \\ Sciences, Zarqa University, Jordan
}

\begin{abstract}
This study is one of very few studies which have investigated the insurance types in the Islamic banks with case study. It explains the need to make financial analysis work papers up to the Insurance types to give fair report. The study finds that there are three Insurance types in Jordanian Islamic Bank which are: Islamic Insurance Company, Tabaduly Insurance Box, and Facing Sharing Investment Risk Box. There is relationship between these types in Jordanian Islamic bank. Every type has way of accounting and way of reduce risk also it has different Place in financial tables up to deferent Fiqh original type and resources of Law. There is need to build suitable financial analysis work papers which show the different of accounting and different of added value than Traditional banks and traditional Insurance companies. Searcher recommended suggestion up to Forth steps to get fair report which is to find resource of investigation, to be sure accounting must meet law, to build paper works up to insurance types, and to use the doubt rule.
\end{abstract}

Keywords: Insurance types, Islamic bank, Financial, Analysis, Work papers.

\section{Contents}

1. Introduction.

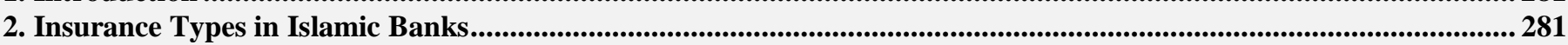

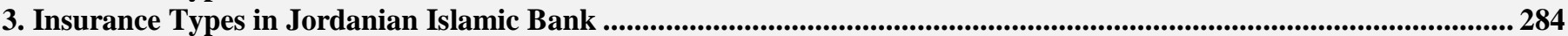

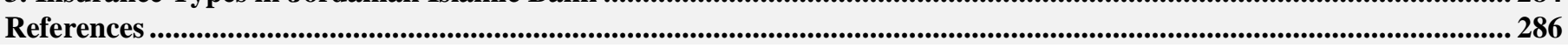

Citation | Abdullah Ibrahim Nazal (2016). Financial Analyst Work Papers to Analysis Insurance Types Affection in Islamic Bank (Jordanian Islamic Bank Case Study). Asian Journal of Social Sciences and Management Studies, 3(2): 280-286.

DOI: $\quad 10.20448 /$ journal.500/2016.3.4/500.4.280.286 $\quad$ crossref

ISSN(E) : $\quad 2313-7401$

ISSN(P): $\quad 2518-0096$

This work is licensed under a Creative Commons Attribution 3.0 License $[(c)$ EY

Funding: This study received no specific financial support.

Competing Interests: The author declares that there are no conflicts of interests regarding the publication of this paper.

Transparency: $\quad$ The author confirm that the manuscript is an honest, accurate, and transparent account of the study was reported; that no

Ethical: vital features of the study have been omitted; and that any discrepancies from the study as planned have been explained.

Ethical:
Publisher:

This study follows all ethical practices during writing.

Asian Online Journal Publishing Group 


\section{Introduction}

Insurance has types up to managing its income which affect on income statement also it has types up to financial and assets managing risk structure which affect on balance sheet. Affection of insurance as way to managing risk is deferent from bank to other because there is no one insurance unit model to all Islamic banks therefore evaluate Islamic bank insurance will give deferent value. Insurance is important to reduce the bank risk in order to get competition ability to face loose or it will lose customers. Customers will get there deposits from the bank which cause loosing finance of its assets and it may lose reputation which leads to loose in its shares speculation value. Insurance will reduce government effort and costs to cover losing in the economic sectors. By time, insurance service become way to reduce unemployment by solve companies' problems and employee staff to work in Insurance companies. Insurance must save customers savings and investing to be acceptable. Benjamine et al. (2011) said there will be reject of projects (as insurance) if the customers do not recognize its value. Pedro and Erwan (2010) said financial tools developing will cause economic developing.

\subsection{The Problem}

As result to external financial analyst misunderstand and to give fair value to Islamic bank insurance there is need to understand its types and ways of managing risk by insurance. Problem questions are: 1- What are insurance types in Islamic banks? 2-What is the affection of insurance on Income statement? 3- What is the affection of insurance on balance sheet? 4- What is the affection of insurance on center bank rules acceptance?

\subsection{The Importance}

Search show Islamic banks ways to use insurance in order to face risks which give deferent financial analysis value and deferent added value. It helps financial analyst to use suitable work papers to get suitable investigation and can compare between deferent Islamic banks to show added value.

\subsection{The Objectives}

Search has aims which are: 1- To find Insurance types in Islamic banks. 2 To find Insurance types affection on Income statement. 3- To find Insurance types affection on balance sheet. 4- To find Insurance affection on center bank rules acceptance.

\subsection{Literature Review}

Mehdi (2010) found that Islamic insurance is second alternative choice for customers because of tradition insurance companies developed services and low level of knowledge about it. Nico and Peiter (2010) discovered that many individuals are not insured round the world because of poor income which needs to promote Islamic Insurance as way get Takaful services against risks for every person from different countries and religions. Justin et al. (2014) explained the important to evaluate companies in crises because there possibility of loss evens it has good reputation also the found that any company which faces crises can reestablish trust by announcing an independent investigation by third party. Kabir and Abdel-Hameed (2002) showed the affect of limits tools choices and explained that financial environment affect on performance of Islamic banks which cause need of suitable ratios and suitable tools. Elsayed (2013)explained the differences of liquidity, credit, risks, profitability and solvency between Islamic banks and Traditional banks therefore banks has different affection in crises.

\section{Insurance Types in Islamic Banks}

Insurance has types depend on the type of risks and sharing in risk. Risk of Islamic bank operations is deferent from bank to other. It's deferent from type of risk and size of risk which will affect on accounting and financing. See next figure:

It is obligatory and depends on center bank rules as deposits Insurance or obligatory reserve which cannot be used to get return. It could be not useful to the bank but it has to buy as obligatory rule to be acceptance in banking sector.

$\rightarrow$ It is Separated and depends on the customer's needs which it is separated from or bank Income statement and balance sheet as customers insurance group up to their depend on the Zakat Box to cover default risks

- It depends on the bank financing and investing structure which affects on the following factors:

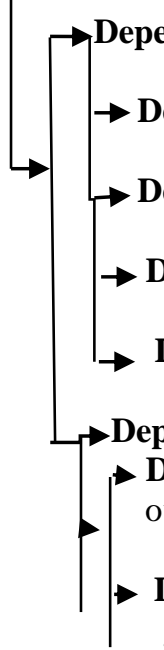

epend on the bank balance sheet

Depend on the bank assets as own Insurance company

Depend on the bank liabilities as get insurance service from other Islamic bank or traditional bank

Depend on the bank equities as managing risk reserve

Depend on transfer operations risks as sharing insurance on Modarabah risk

$\rightarrow$ Depend on the bank Income statement

Depend on the return in Income statement as get commission of managing or get return of its investing or own installments insurance as Profitability Company

Depend on the expenses in income statement as added buying insurance expenses or bank sharing with group of banks as insurance electronic card service expenses 


\subsection{Islamic Insurance Company}

Insurance companies could be donate or profitability. The type will affect on financial analysis work papers. Every type has way to be calculated. If the Islamic bank own insurance company the bank will affected by its return, bank operation return and its credit classification type increasing.

Donate Islamic Insurance company show that customers buy installments as sharing in risk for limit time. If the risk happens it will be reduced from this sharing, See next table:

Table-1. Donate Islamic Insurance Company accounting

\begin{tabular}{l|l|l}
\hline $\begin{array}{l}\text { Suppose sharing of buying all loose of } \\
\text { sharer in the insurance company and } \\
\text { suppose the amount of installment from } \\
\text { all customers (sharers) for the limit time } \\
\text { of sharing = 100000\$ and loose as follow: }\end{array}$ & $\begin{array}{l}\text { Return of customers after the } \\
\text { contract time ended }\end{array}$ & $\begin{array}{l}\text { Suppose returns of } \\
\text { the Islamic insurance } \\
\text { company as manger } \\
\text { (work return) and it } \\
\text { will take 20000 \$ }\end{array}$ \\
\hline 1- Loose from all sharer in the risk $=50000 \$$ & $\begin{array}{l}30000 \\
\text { It will divided on the customers number } \\
\text { and they get it as return of savings }\end{array}$ & 20000 \\
\hline $\begin{array}{l}\text { 2-Loose from all sharer in the risk }= \\
\text { 100000\$ }\end{array}$ & $\begin{array}{l}\text { Therefore it will not cover all loose but } \\
\text { part of loose and looser must buy the } \\
\text { other part because of limit sharing by } \\
\text { installments and time }\end{array}$ & 20000 \\
\hline 3- loose from all sharers in the risk = Zero & $\begin{array}{l}80000 \\
\text { It will divided on the customers number } \\
\text { and they get it as return of savings }\end{array}$ & 20000 \\
\hline Source: prepared by searcher &
\end{tabular}

The insurance company gets return as manager (work contract return). Customers own the installments as savings and donate is done just when there is loose therefore donate equal loose.

When Islamic bank own profitability Islamic insurance company which show in its assets as owning companies. The value of this company will affect on assets value. When the company makes suitable return it will increase the bank returns and assets value. Practically, it gives the bank increase credit classification as result to reduce risks also courage customers to deal with bank operations without fear of default. Calculating return is deferent from donate Islamic Insurance companies. See next table:

Table-2. Profitability Islamic Insurance Company accounting

\begin{tabular}{|c|c|c|}
\hline $\begin{array}{l}\text { Suppose sharing of buying } 60 \% \text { of sharer } \\
\text { loose in the insurance company and } \\
\text { suppose the amount of installment from } \\
\text { all customers (sharers) for the limit time } \\
\text { of sharing }=100000 \$ \text { and loose as follow: }\end{array}$ & $\begin{array}{l}\text { Return of customers after the } \\
\text { contract time ended }\end{array}$ & $\begin{array}{l}\text { returns of the Islamic } \\
\text { Insurance company as } \\
\text { owner }\end{array}$ \\
\hline $\begin{array}{l}\text { 1- Loose from all sharer in the risk }=50000 \$ \\
\text { which it less than } 60 \% \text { of all installment }\end{array}$ & Zero & 50000 \\
\hline $\begin{array}{l}\text { 2-Loose from all sharer in the risk = } \\
100000 \$\end{array}$ & $\begin{array}{l}\text { Zero } \\
\text { And loser must cover the risk of } 40000\end{array}$ & 40000 \\
\hline 3- loose from all sharers in the risk $=$ Zero & Zero & 100000 \\
\hline
\end{tabular}

Source: prepared by searcher

Case of reselling the insurance installments is affected on profitability return. This type happened if the rules of the country accepted. In some cases as customer default to buy installments Insurance companies transfer the risk by sell the contracts to other Islamic insurance companies. It may sell some contracts with commission or sell contract with part of loose or sell all contract with commission or sell all contracts without returns, see next table:

Table-3. Profitability Islamic Insurance Company accounting in reselling contracts before risk

\begin{tabular}{l|l|l}
\hline $\begin{array}{l}\text { suppose the amount of installment from } \\
\text { all customers (sharers) for the limit time } \\
\text { of sharing = 100000\$ and reselling } \\
\text { contracts as follow: }\end{array}$ & $\begin{array}{l}\text { returns of the Islamic } \\
\text { Insurance company as seller }\end{array}$ & $\begin{array}{l}\text { returns of the Islamic Insurance } \\
\text { company as buyer }\end{array}$ \\
\hline 1- Sell all contracts without return & Zero & 100000 if loose not happen \\
\hline 2- Sell all contracts with commission =5000 & 5000 & 95000 if loose not happen \\
\hline 3- Sell all contracts with loose $=5000$ & $5000-$ & 105000 if loose not happen \\
\hline $\begin{array}{l}\text { 4- sell part of contract as 50\% with loose } \\
\text { 2000 }\end{array}$ & $50000-2000=48000$ & $50000+2000$ if loose not happen \\
\hline $\begin{array}{l}\text { 5- sell part of contract as 50\% with } \\
\text { commission = 2000 }\end{array}$ & $50000+2000=52000$ & $50000-2000$ if loose not happen \\
\hline Source: prepared by searcher
\end{tabular}

Some Islamic banks use part of the installment in investing before the contract limit time end. It may increase its return or make other loose. Financial analyst must understand insurance companies accounting and its factors to increase Islamic bank returns in income statement or increase its expenses also he has to understand the value of Insurance company as success investing on assets value which increase equities or understand the insurance company loose investing on assets value which reduce equities. 


\subsection{Tabaduly Insurance Box (Corporate Insurance)}

The question: Is the bank own all customers installments in Tabaduly Insurance or not? It may own the Tabaduly Insurance which means it is services as assets and reselling from Tabaduly Insurance contracts will reduce the asset and reduce its returns up to installments size but when installments are donate from customers and Tabaduly Insurance become as guarantor up to conditions. In this case, it affects on bank risk classification type positively and give return up to managing but it is not become the bank assets therefore it becomes liabilities so that it cannot reselling the contracts to other insurance company. Tabaduly Insurance is other way to managing risks. It gives every dealer in delay selling or in lease and sell contract operation to buy donates related to buying installments number which must be bought by customer. The donate installments will be collected as sharing from customers to cover their self in default case. Ex: if any customer sharer in the Tabaduly Insurance died the insurance will buy all the last installments. It helps bank to get his money and helps heirs to pay the credit of the deceased. It has rule: (just buy in case of death or get in chronic illness). Practically, Tabaduly Insurance accounted as follow:

\{(Percent from $5 \%$ to $10 \%$ depend on the increasing of the installment numbers) $\mathrm{X}$ finance value $\}$

Ex: Suppose the bank finance selling car $=20000$ for 120 monthly installments and Tabaduly Insurance $=5 \%$. There will be cases as in the next table:

Table-4. Cases of Tabaduly Insurance affection

\begin{tabular}{|c|c|c|c|}
\hline $\begin{array}{l}\text { The size of Tabaduly } \\
\text { Insurance for every } \\
\text { month }(20000 * 5 \%) / \\
120=8,33333333\end{array}$ & $\begin{array}{l}\text { In case 1: Customer has default } \\
\text { to buy after } 100 \text { installment but } \\
\text { customer not die or get in } \\
\text { chronic illness }\end{array}$ & $\begin{array}{l}\text { In case 2: } \\
\text { after he boughtomer } \\
\text { installment } 100\end{array}$ & $\begin{array}{l}\text { In case 3: customer } \\
\text { complete buying all } \\
120 \text { installments }\end{array}$ \\
\hline The bank return & $\begin{array}{l}\text { Is not completed and cannot get } \\
\text { from Tabaduly Insurance } \\
\text { therefore it ask for guarantor to } \\
\text { complete buying the installments }\end{array}$ & $\begin{array}{lcc}\text { Completed } & \text { bout } & \text { after } \\
\text { customer } \quad \text { died } & \text { from } \\
\text { Tabaduly Insurance } & \end{array}$ & $\begin{array}{l}\text { Completed } \\
\text { customer }\end{array}$ \\
\hline The customer credit & $\begin{array}{l}\text { Still and guarantor will complete } \\
\text { buying the installments }\end{array}$ & $\begin{array}{l}\text { Zero (Ended by Tabaduly } \\
\text { Insurance) }\end{array}$ & Zero \\
\hline $\begin{array}{l}\text { The Tabaduly } \\
\text { Insurance accounting }\end{array}$ & Increase 833,33333 & $\begin{array}{l}\text { Decrease }(8,33333333 * 20 \\
\text { installments }=166,66667)\end{array}$ & Increase 1000 \\
\hline
\end{tabular}

\subsection{Facing Sharing Investment Risk Box}

This account is related to sharing investment account. It is show that the bank is sharing by Modarabah. The bank did not use his capital to get in sharing. If there is loose, the bank will just loose effort but customers will loose from their capital. Facing sharing investment risk accounting is way to managing risks. The law organizes dealing by this account. Every year sharing investment account has profit or loose. The rules are as follow:

1- If loose is happened in sharing investment account within the year it will be covered by sharing investment account profit not from facing sharing investment risk accounting.

2 - If loose is happened in sharing investment account within the year and it is more than sharing investment account profit within the year, loose will be covered by facing sharing investment risk accounting.

3- If sharing investment account had investing for many years because investing is more than year and not shown the return until the end of these years, in this case loose will be bought by facing sharing investment risk accounting

The idea is: Facing sharing investment risk accounting is guarantor for the next year of investing loose. It must be gotten by law. It is equal $10 \%$ to $20 \%$ from the sharing investment account profit. In this idea, facing sharing investment risk accounting is liability. There are cases of dealing in this account, See next table:

Table-5. Cases of facing sharing investment risk accounting

\begin{tabular}{|c|c|c|c|}
\hline $\begin{array}{l}\text { Suppose } \\
\text { sharing investment risk } \\
\text { accounting } \\
100000 \\
\text { And it must be } 10 \% \\
\text { from profit of sharing } \\
\text { investment account }\end{array}$ & $\begin{array}{l}\text { No loose happen in this } \\
\text { year }\end{array}$ & $\begin{array}{l}\text { Loose equal } 20000 \text { but profit } \\
=10000\end{array}$ & $\begin{array}{l}\text { Loose equal } 20000 \text { but } \\
\text { profit } 100000 \\
\text { This mean the profit will } \\
\text { be } 80000 \text { and facing } \\
\text { sharing investment risk } \\
\text { accounting must get } 10 \%\end{array}$ \\
\hline The bank result & $\begin{array}{l}\text { Liability of facing sharing } \\
\text { investment risk accounting } \\
\text { equal } 100000\end{array}$ & $\begin{array}{l}\text { Liability of facing sharing } \\
\text { investment risk accounting equal } \\
90000 \text { as covering } 10000 \text { loose }\end{array}$ & $\begin{array}{l}\text { Liability of facing sharing } \\
\text { investment risk accounting } \\
\text { equal } 100000+8000\end{array}$ \\
\hline $\begin{array}{lr}\text { The facing sharing } \\
\text { investment } \\
\text { accounting result }\end{array}$ & equal 100000 & Equal 90000 & equal 108000 \\
\hline
\end{tabular}

The law is related to sharing investment account therefore when the bank loose sharing by his capital it will not be covered by facing sharing investment risk accounting. Facing sharing investment risk accounting helps to increase credit classification type just in sharing investment account.

Suppose: the bank own facing sharing investment risk accounting, what will happen? It will face problem of forbidden Islamic rule: that the bank (Modarib) will by loose from his assets which will be against Islamic rule of Modarabah but when the facing sharing investment risk accounting is related to sharing contracts by bank capital and customer capital, there will be accepted Islamic rule to cover loose depend on the rule size of loose increased by capital sharing on other hand when the bank own the facing sharing investment risk accounting it will be increasing of assets and equities. This means that deferent of original type of any account will cause deferent affect on income 
statement and balance sheet. Financial analyst must understand original type of any account and its size, time, and affection on balance sheet or income statement.

\section{Insurance Types in Jordanian Islamic Bank}

Jordanian Islamic Bank is oldest bank in Jordan. It follows Jordan center bank rules and Jordan Islamic bank rules which obligate the bank to deal with Islamic bank services up to Islamic rules. To understand insurance type accounts there are needs to get the bank rule, financial tables, explanations, related reports, reputation and doubt base. Jordanian Islamic Bank has three types of insurance.

\subsection{Facing Sharing Investment Risk Accounting Box}

The Jordanian Islamic Bank Annual Report (2005) explained the Insurance types accounting data. It showed facing sharing investment risk accounting which was applied as result to standard no (17). It was taken from net income before tax and fees as adjusted of operation cash flow that had been shown in cash flow table. Income statement showed the note no (13). Note no (13) explain factors of facing sharing investment risk accounting box. See next table:

Table-6. Factors of facing sharing investment risk accounting box

\begin{tabular}{l|l|l}
\hline The data & $\mathbf{3 1 / 1 2 / 2 0 0 5}$ & $\mathbf{3 1 / 1 2 / 2 0 0 4}$ \\
\hline $\begin{array}{l}\text { facing sharing investment risk accounting box at the } \\
\text { first of the year }\end{array}$ & $23,996,224$ & $22,092,931$ \\
\hline $\begin{array}{l}\text { Buying Income tax on the facing sharing investment } \\
\text { risk accounting box }\end{array}$ & $(1,163,446)$ & $(1,713,148)$ \\
\hline Net tax settlement for 2003 & 59,115 & - \\
\hline $\begin{array}{l}\text { The transformer from yearly investment }=10 \% \text { of } \\
\text { sharing investment account net profit in } 2004 \text { and it } \\
\text { increase in } 2005 \text { to be } 15 \%\end{array}$ & $8,009,176$ & $3,616,441$ \\
\hline $\begin{array}{l}\text { sharing investment account risks box at the end of } \\
\text { the year }\end{array}$ & $30,901,069$ & $23,996,224$ \\
\hline Source: JIBAR (2005). & \\
\hline
\end{tabular}

The note no (3): explain that the box buy tax and did not explain any loose by sharing investment account risks in 2004and 2005.

The account rule of the Jordanian Islamic bank in 2000 no (28) including item no (55) of the box give expectations: If any loose happened in 2005 it would be decreased from the net profit of the sharing investment account but if the loose become more than profit in 2005 it will be reduced from the box account in 2004. And any loose because of the bank managing with assault and a shortening it will be cover by bank capital.

Balance sheet showed that the box is asset but it not show the way of its finance as own by liabilities or equities but the box rule show it is liabilities. JIBAR (2015) showed the distributed of the box as in the next table:

Table -7. Distributed of the Factors of facing sharing investment risk accounting box

\begin{tabular}{l|l}
\hline \multicolumn{1}{|c}{ Table -7. Distributed of the Factors of facing sharing investment risk accounting box } \\
\hline The mount in the last year & $\mathbf{3 1 / 1 2 / 2 0 1 5}$ \\
\hline To cover reducing of delay sales debts & $91,752,989$ \\
\hline To cover reducing of lease and sale debts & $75,761,684$ \\
\hline To cover reducing of financing & $1,538,075$ \\
\hline To cover reducing of owning buildings & 173,196 \\
\hline All the amount of reducing & 3,676 \\
\hline Tabaduly Insurance box to cover reducing of delay sales debts contract & $77,483,502$ \\
\hline Tabaduly Insurance box to cover reducing of lease and selling debts contract & $(5,602,526)$ \\
\hline The amount of the box after reducing & $(36,060)$ \\
\hline Source: JIBAR (2015) & $19,908,073$ \\
\hline
\end{tabular}

As result to the explanation, financial analyst has to find possibility of buying from the boxes for one reason to avoid duplication of buying.

\subsection{Islamic Insurance Company}

JIBAR (2005) explained that $35 \%$ of the Islamic Insurance company shares owned by the bank. It is part of Jordanian Islamic bank assets. The company fair value increased from $2004-2005$ and give the bank growth of assets value. It helps bank to reduce risks of selling cars, houses and others by installments as result to protect its value from accidents also gave distributed return. The annual report did not show the distributed return but the annual report of the Islamic Insurance Company will give this explanation. JIBAR (2015) showed that the bank reduced his sharing in the Islamic Insurance Company from $35 \%$ to be $33.4 \%$.

\subsection{Tabaduly Insurance}

It was found in 1994. It managing risks by conditions as increasing installment value with up to increasing installments number and increasing of credit amount also there is limit age to accept sharing. JIBAR (2005) explained the Tabaduly Insurance box. It included 13, 8 million JD It covered default of 78 cases by buying (239400) JD and has (71196) sharers. Their credit was $(174,9)$ million JD. JIBAR $(2015)$ showed adjusted of the customers' amount. It increased the amount of customer credit to share in the box in order to increase customers also it accepted to give compensation in case of customer get in continuous financial default. By the end of the year 2015 the box 
was included $(64,2)$ million for $(138000)$ customers to cover their credit which equal $(982)$ million. It showed the explanation of the box as in the next table:

Table-8. Tabaduly Insurance accounting details in 2015/2014

\begin{tabular}{|c|c|c|}
\hline Items & $31 / 12 / 2015$ & $31 / 12 / 2014$ \\
\hline Amount of the box when the year start & $53,590,986$ & $44,652,078$ \\
\hline Added profits of box investing in 2013 and 2014 & $1,675,081$ & $1,249,397$ \\
\hline Added the installments that gotten within the year & $17,007,692$ & $13,803,945$ \\
\hline Reduce Insurance installment that was bought to the Islamic Insurance Company & $(3,287,685)$ & $(2,480,163)$ \\
\hline Reduce part of tax which was bought for $2014 / 2015$ & $(916,590)$ & $(560,366)$ \\
\hline Reduce Income tax of the box for the year & $(3,090,203)$ & $(2,669,289)$ \\
\hline Reduce gifts for the box committee members & $(16,000)$ & $(16,000)$ \\
\hline Reduce Auditor box accounting return & $(1,740)$ & - \\
\hline Redeemed losses & $(725,271)$ & $(388,616)$ \\
\hline All amount of the box & $64,236,270$ & $53,590,986$ \\
\hline
\end{tabular}

Source: JIBAR (2015).

The table shows relationship between Tabaduly Insurance and Islamic Insurance Company.

Conclusion: This study is one of very few studies which have investigated the insurance types in the Islamic banks with case study. It explains the need to make financial analysis work papers up to the Insurance types to give fair report. The study finds that there are three Insurance types in Jordanian Islamic Bank which are: Islamic Insurance Company, Tabaduly Insurance Box, and Facing Sharing Investment Risk Box. There is relationship between these types in Jordanian Islamic bank. Every type has way of accounting and way of reduce risk also it has different Place in financial tables up to deferent Fiqh original type and resources of Law. There is need to build suitable financial analysis work papers which show the different of accounting and different of added value than Traditional banks and traditional Insurance companies.

Recommendations: searcher suggests steps to build financial analyst work papers to analysis Insurance types in Islamic bank as follow:

First: find resource of investigation because financial work paper analysis at the end of the year must meet the real accounting way of insurance installments return, expenses and insurance box value. The direct way is to ask the internal accountant but the indirect way it to see the annual report, notes, explanations, comparing data accounting with the other years to find change of accounting policy and its affects, law of the bank, law of the center bank, the law of the insurance company, and Insurance company annual report. Some financial analyst has funds to make investigation in courts and the market to find changing of reputation

Second: be sure accounting must meet law as center bank law, bank law, and Insurance Company law without conflict or there will be problem of added value and possibility of punishment fine which cause loose of equity and not shown in income or balance sheet.

Third: built paper works up to insurance types. Ex: build expect paper work for the financial analyst to analysis insurance types of Jordanian Islamic Bank. It is fixed up to the insurance types and its conditions, See next table:

Table-9. Insurance types of accounting data in Islamic bank

\begin{tabular}{|c|c|c|c|c|c|c|}
\hline $\begin{array}{l}\text { Insurance } \\
\text { Types }\end{array}$ & $\begin{array}{l}\text { Type } \\
\text { customer }\end{array}$ & $\begin{array}{l}\text { Customer } \\
\text { duties }\end{array}$ & $\begin{array}{l}\text { Customer } \\
\text { rights }\end{array}$ & Islamic bank duties & Islamic Bank rights & $\begin{array}{l}\text { Possibility } \\
\text { managing risk }\end{array}$ \\
\hline $\begin{array}{l}\text { Islamic } \\
\text { Insurance } \\
\text { company }\end{array}$ & $\begin{array}{l}\text { Buying in } \\
\text { selling } \\
\text { contract or } \\
\text { leasing by } \\
\text { delay } \\
\text { installments to } \\
\text { face accidents }\end{array}$ & $\mid \begin{array}{ll}\text { Buy } & \text { all } \\
\text { Insurance } & \\
\text { installments } & \\
\text { within } & \text { the } \\
\text { insurance } & \\
\text { agreement } & \end{array}$ & $\begin{array}{l}\text { Reduce possible } \\
\text { lose up to the } \\
\text { type of } \\
\text { insurance risk as } \\
\text { fire, illness and } \\
\text { transport risks }\end{array}$ & $\begin{array}{l}\text { own installments and } \\
\text { managing insurance } \\
\text { contracts to buy loose } \\
\text { as in the insurance } \\
\text { contract conditions } \\
\text { and buy profit tax }\end{array}$ & $\begin{array}{l}\text { Own the installments } \\
\text { which mean it is the } \\
\text { bank asset }\end{array}$ & $\begin{array}{l}\text { Resell the insurance } \\
\text { contract or reduce } \\
\text { compensation by rules }\end{array}$ \\
\hline $\begin{array}{l}\text { Tabaduly } \\
\text { Insurance }\end{array}$ & $\begin{array}{l}\text { Buying in } \\
\text { selling } \\
\text { contract or } \\
\text { leasing by } \\
\text { delay } \\
\text { installments to } \\
\text { face default } \\
\text { by death or } \\
\text { chronic illness }\end{array}$ & \begin{tabular}{|lr} 
Buy & all \\
Insurance & \\
installments & \\
within & the \\
insurance & \\
agreement & \\
& \\
& \\
\end{tabular} & $\begin{array}{l}\text { Reduce possible } \\
\text { loose of } \\
\text { customer default } \\
\text { by death or } \\
\text { chronic illness }\end{array}$ & $\begin{array}{l}\text { Managing insurance } \\
\text { contracts to buy loose } \\
\text { as in the insurance } \\
\text { contract conditions }\end{array}$ & $\begin{array}{l}\text { Islamic bank avoid } \\
\text { customer default of } \\
\text { delay buying by } \\
\text { installment or leasing } \\
\text { by installment } \\
\text { which mean it is the } \\
\text { bank liability Also } \\
\text { bank get return of } \\
\text { managing and work }\end{array}$ & $\begin{array}{l}\text { Increasing installment } \\
\text { price up to increasing } \\
\text { installments numbers and } \\
\text { increasing amount of } \\
\text { contract also conditions of } \\
\text { contract obligate limit age } \\
\text { as customer age must be } \\
\text { less than } 65 \text { year at the end } \\
\text { of the contract }\end{array}$ \\
\hline $\begin{array}{l}\text { Facing } \\
\text { sharing } \\
\text { investment } \\
\text { risk } \\
\text { accounting }\end{array}$ & $\begin{array}{l}\text { Share in } \\
\text { investing } \\
\text { contract by } \\
\text { capital to face } \\
\text { bank } \\
\text { managing } \\
\text { loose but bank } \\
\text { just has } \\
\text { shared by } \\
\text { effort }\end{array}$ & \begin{tabular}{|l} 
Buy part of \\
sharing \\
investment \\
account profit
\end{tabular} & $\begin{array}{l}\text { Reduce possible } \\
\text { loose of bank } \\
\text { managing } \\
\text { sharing } \\
\text { investing } \\
\text { account } \\
\text { (Modarib) }\end{array}$ & $\begin{array}{l}\text { Managing insurance } \\
\text { contracts to buy loose } \\
\text { as in the insurance } \\
\text { contract conditions } \\
\text { and buy the account } \\
\text { tax }\end{array}$ & $\begin{array}{l}\text { Transfer risk of bank } \\
\text { managing loose in } \\
\text { sharing investment } \\
\text { account to the account } \\
\text { of facing sharing } \\
\text { investment risk which } \\
\text { mean it is the bank } \\
\text { liability Also bank get } \\
\text { return of managing } \\
\text { and work }\end{array}$ & $\begin{array}{l}\text { Increase buying part of } \\
\text { sharing investment account } \\
\text { from } 10 \% \text { to } 15 \%\end{array}$ \\
\hline
\end{tabular}

Source: prepared by searcher

Forth: use the doubt rule. Financial account data by doubt rule will give discussions as follow:

1 - Discuss this table account data if it is done actually as expect 
2-Discuss this table account data if it is fixed to the income statement and balance sheet. 3- Discuss the affection of possibility account managing risk on changing of data and the aim of this change. 4- Compare between loose and possibility of trick.

5- Compare between changing of accounting managing risk and possibility of trick as covering manager defaults or his friends or wife or brothers with possibility that contracts did not include conditions or grantee as other customers. 6- Discuss the insurance type account and added value to employee, customer, shareholders, creditors and government.

7- Discuss the relationship between these three boxes as way to reduce the bank risk which supported by center bank rules. The questions are:

$7-1$ is the boxes reduce bank risk and customer risk?

7-2 Is there are relationships between the three boxes as duplication of compensation payment for one risk from more than one box or is the box support other box and what is the relation affection on customers, bank, creditors, government and employees?

\section{References}

Benjamine, L., P.L. Andrew and W. Randall, 2011. Information and liquidity. Journal of Money, Credit and Banking, Wiley Black Well, Ohio State University,USA, 43(7): 356.

Elsayed, E., 2013. Comparative analysis of Qatar islamic banks performance versus conventional banks before, during and after the financial crisis. International Journal of Business and Commerce, 3(3): 11-41

JIBAR, 2015. No: Thirty seventh. Amman, Jordan: The Sharq Publisher. pp: 27, 119.

Justin, H., D. Daniel and L.U. Eric, 2014. Unlikely allies: Credibility transfer during corporate crises. Journal of Applied Social Psychology, 44(5): 392-397.

Kabir, H.M. and B.M. Abdel-Hameed, 2002. Determinants of islamic banking profitability. ERF Paper: 2. Retrieved from http://www.kantakji.com.

Mehdi, S., 2010. The evaluation of islamic insurance - takaful: A literature survey. Insurance Markets and Companies Analysis and Actuarial Computations, 1(2): 102, 105,106.

Nico, P. and C. Peiter, 2010. Takaful: An islamic insurance instrument. Journal of Development and Agriculture Economics, 2(10): 333-339.

Pedro, A.S. and Q. Erwan, 2010. Limited enforcement, financial intermediation, and economic development: A quantitative assessment. International Economic Review, 51(3): 785-811.

The Jordanian Islamic Bank Annual Report, 2005. No: Twenty seventh. Amman, Jordan: The Sharq Publisher. pp: 21,29,56,57,59,73,76. 